\title{
PENGARUH MODEL PROBLEM BASED LEARNING DAN KEMAMPUAN BERPIKIR KRITIS TERHADAP KEMAMPUAN PEMECAHAN MASALAH
}

\author{
Unita S. Zuliani Nasution, Sahyar, Makmur Sirait
}

\begin{abstract}
Abstrak. Penelitian ini bertujuan untuk menganalisis perbedaan kemampuan pemecahan masalah fisika menggunakan model pembelajran problem based learning dan pembelajaran dengan model pembelajaran direct instruction, perbedaan kemampuan pemecahan masalah fisika antara siswa yang memiliki kemampuan berpikir kritis di atas rata-rata dengan siswa yang memiliki kemampuan berpikir kritis di bawah rata-rata, dan interaksi model pembelajaran problem based learning dengan kemampuan berpikir kritis terhadap kemampuan pemecahan masalah fisika siswa. Penelitian ini merupakan penelitian quasi eksperimen. Instrumen yang digunakan terdiri dari tes kemampuan pemecahan masalah dan tes kemampuan berpikir kritis. Hasil penelitian menunjukkan bahwa kemampuan pemecahan masalah fisika siswa yang menggunakan model pembelajaran berbasis masalah lebih baik dibandingkan dengan pembelajaran langsung, kemampuan pemecahan masalah fisika siswa dengan kemampuan berpikir kritis di atas rata-rata menunjukkan perbedaan dan hasil yang lebih baik dari pada siswa dengan kemampuan berpikir kritis di bawah rata-rata, serta terdapat interaksi antara model pembelajaran berbasis masalah dan kemampuan berpikir kritis dalam mempengaruhi kemampuan pemecahan masalah fisika siswa.
\end{abstract}

Katakunci: Model Pembelajaran Berbasis Masalah, Kemampuan Berpikir Kritis, Kemampuan Pemecahan Masalah

\section{EFFECT OF PROBLEM BASED LEARNING AND MODEL CRITICAL THINKING ABILITY TO PROBLEM SOLVING SKILLS}

\author{
Unita S. Zuliani Nasution, Sahyar, Makmur Sirait
}

\begin{abstract}
The purposes of this research were to analyze the different between physic resolving problem ability by using problem based learning model and direct instruction model, the different of physic resolving problem ability between the students that have critical thinking ability upper the average and the students that have critical thinking ability under the average, and the interaction of problem based learning model toward critical thinking ability and students' physic resolving problem ability. This research was quasy experimental research that use critical thinking ability tests and physic resolving problem ability tests as the instruments. Result of the research showed that the students' physic resolving problem ability by using problem based learning model was better than by using direct instruction model, students' physic resolving problem ability and critical thinking ability upper the average showed better different and result than students' critical thinking ability under the average, besides there was an
\end{abstract}


U. S. Z. Nasution, Sahyar, M. Sirait: Pengaruh Model Problem Based Learning dan Kemampuan Berfikir Kritis Terhadap Kemampuan Pemecahan Masalah
Jurnal Pendidikan Fisika p-ISSN2252-732X e-ISSN 2301-7651

interaction between problem based learning model and critical thinking ability in improving students' physic resolving problem ability.

Keywords: Problem based learning model, critical thinking ability, resolving problem ability

\section{PENDAHULUAN}

Pelajaran fisika di kalangan SMA masih berupa kumpulan konsep yang dihapal sehingga berdampak pada rendahnya kemampuan peserta didik pada aspek kognitif. Aspek kognitif terdiri dari enam aspek, yaitu : mengingat, memahami, menerapkan, menganalisis, mengevaluasi, dan menciptakan. Namun, pada kenyataannya aspek tingkat tinggi seperti analisis mengolah masalah, mengevaluasi, dan menciptakan belum biasa dilatihkan kepada peserta didik. Sehingga peserta didik masih kesulitan dalam menerapkan pengetahuan yang dimiliki dalam kehidupan sehari-hari. Selain itu, peserta didik juga belum mampu menyelesaikan suatu permasalahan yang didahului dengan penyelidikan. Apabila prinsip penyelesaian masalah ini diterapkan dalam pembelajaran, maka peserta didik dapat terlatih dan membiasakan diri berfikir kritis secara mandiri. Kemampuan berpikir kritis adalah mode berpikir-mengenai hal, substansi atau masalah apa saja- di mana si pemikir meningkatkan kualitas pemikirannya dengan menangani secara terampil struktur-struktur yang melekat dalam pemikiran dan menerapkan standar-standar intelektual padanya (Alec Fisher , 2002). Sementara itu, kemampuan berfikir kritis melatih peserta didik untuk membuat keputusan dari berbagai sudut pandang secara cermat, teliti, dan logis. Dengan kemampuan berfikir kritis peserta didik dapat mempertimbangkan pendapat orang lain serta mampu mengungkapkan pendapatnya sendiri. Oleh karena itu, diharapkan pendidikan di sekolah terutama dalam pembelajaran fisika siswa dilatih untuk menggali kemampuan dan keterampilan dalam mencari, mengolah, dan menilai berbagai informasi secara kritis. Dengan kemampuan berpikir kritis siswa akan lebih mudah memecahkan permasalahan dalam fisika secara cermat, sistematis, dan logis dengan berbagai sudut pandang. Kemampuan berpikir kritis diperoleh melalui suatu latihan atau situasi yang sengaja diciptakan untuk merangsang seseorang berpikir secara kritis, misalnya melalui kegiatan pembelajaran. Pembelajaran fisika yang dilaksanakan pada setiap jenjang pendidikan, hendaknya menekankan pada pemberian pengalaman langsung. Adanya pengalaman tersebut akan mengembangkan kemampuan berpikir siswa. Siswa diarahkan untuk mencari tahu dan pengetahuan yang tinggi dalam memecahkan suatu fenomena alam. Oleh karena itu pendekatan yang diterapkan dalam menyajikan pembelajaran fisika adalah memadukan antara pengalaman proses dan pemahaman produk. Hal ini sesuai dengan tingkat perkembangan mental siswa SMA yang berada dalam tahap transisi antara berpikir konkret operasional ke berpikir formal. Pembelajaran PBL merupakan suatu pendekatan pengajaran yang menggunakan masalah dunia nyata sebagai suatu konteks bagi peserta didik untuk belajar cara berpikir kritis dan keterampilan memecahkan masalah, serta untuk memperoleh pengetahuan dan konsep yang esensial dari materi pelajaran. Dalam PBL peserta didik diharapkan bisa mempunyai kemampuan berpikir kritis dalam menerima pembelajaran di dalam kelas.

Melalui jurnal penelitian seperti yang dilakukan oleh Afandi S. dan Widhia S (2012) mengatakan interaksi antara model pembelajaran dengan kemampuan berpikir kritis secara signifikan mempengaruhi prestasi belajar mahasiswa. Sedangkan Idayati,dkk (2013) mengatakan terdapat interaksi antara model pembelajaran dan berpikir kritis ke IPA-Fisika terhadap hasil belajar IPA-Fisika siswa. Pada siswa dengan keterampilan berpikir kritis ke IPA-Fisika tinggi hasil belajar siswa dengan menggunakan model pembelajaran problem based learning (PBL) sama dengan menggunakan model pembelajaran jigsaw. Pada siswa dengan keterampilan berpikir ke IPA-Fisika rendah hasil belajar siswa dengan menggunakan model pembelajaran problem based learning (PBL) lebih rendah dibandingkan dengan menggunakan model pembelajaran Jigsaw.

\section{METODE PENELITIAN}

Desain penelitian yang digunakan adalah desain yang menggunakan pretes dan postes. Desain ini merupakan yang paling efektif dalam istilah penunjukan hubungan sebab akibat. Penelitian ini melibatkan dua kelas yaitu kelas kontrol dan kelas eksperimen yang diberi perlakukan berbeda. Pada kelas eksperimen diberi perlakuan model pembelajaran berbasis masalah (problem based learning) dan pada kelas kontrol diberi perlakuan pembelajaran Direct instruction. Adapun desain penelitian untuk ANAVA 2X2 dapat ditunjukan pada Tabel.1:

Tabel 1. Desain Penelitian ANAVA 2X2

\begin{tabular}{ccc}
\hline Kemampu & \multicolumn{2}{c}{ Pemecahan Masalah } \\
\cline { 2 - 3 } an Berfikir & $\begin{array}{c}\text { Model Direct } \\
\text { Kritis }(B)\end{array}$ & $\begin{array}{c}\text { Model PBL } \\
\text { instruction }\left(\mathrm{A}_{1}\right)\end{array}$ \\
\cline { 2 - 3 } Rendah & $\left.\mathrm{A}_{2}\right)$ \\
$\left(\mathrm{B}_{1}\right)$ & $\mathrm{A}_{1} \mathrm{~B}_{1}$ & $\mathrm{~A}_{1} \mathrm{~B}_{2}$ \\
Tinggi $\left(\mathbf{B}_{2}\right)$ & & \\
& $\mathrm{A}_{2} \mathrm{~B}_{1}$ & $\mathrm{~A}_{2} \mathrm{~B}_{2}$ \\
$\mu_{\mathrm{A} 1}$ & $\mu_{\mathrm{A} 2}$ \\
\hline
\end{tabular}


U. S. Z. Nasution, Sahyar, M. Sirait: Pengaruh Model Problem Based Learning dan Kemampuan Berfikir Kritis Terhadap Kemampuan Pemecahan Masalah

\begin{tabular}{|c|c|c|}
\hline $\mathrm{A}_{1} \mathrm{~B}_{1}$ & $=$ & Rata-rata kemampuan \\
\hline & & pemecahan masalah fisika siswa \\
\hline & & yang diajarkan dengan \\
\hline & & menggunakan model direct \\
\hline & & instruction untuk kelompok \\
\hline & & siswa yang mempunyai \\
\hline & & $\begin{array}{l}\text { kemampuan berfikir kritis } \\
\text { rendah }\end{array}$ \\
\hline $\mathrm{A}_{1} \mathrm{~B}_{2}$ & $=$ & Rata-rata kemampuan \\
\hline & & pemecahan masalah fisika siswa \\
\hline & & yang diajarkan dengan \\
\hline & & menggunakan model direct \\
\hline & & instruction untuk kelompok \\
\hline & & siswa yang mempunyai \\
\hline & & kemampuan berfikir kritis tinggi \\
\hline $\mathrm{A}_{2} \mathrm{~B}_{1}$ & $=$ & $\begin{array}{l}\text { Rata-rata kemampuan } \\
\text { pemecahan masalah fisika siswa }\end{array}$ \\
\hline & & yang diajarkan dengan \\
\hline & & menggunakan model PBL untuk \\
\hline & & kelompok siswa yang \\
\hline & & $\begin{array}{l}\text { mempunyai kemampuan berfikir } \\
\text { kritis rendah }\end{array}$ \\
\hline $\mathrm{A}_{2} \mathrm{~B}_{2}$ & $=$ & Rata-rata kemampuan \\
\hline & & pemecahan masalah fisika siswa \\
\hline & & yang diajarkan dengan \\
\hline & & menggunakan model PBL untuk \\
\hline & & kelompok siswa yang \\
\hline & & $\begin{array}{l}\text { mempunyai kemampuan berfikir } \\
\text { kritis tinggi }\end{array}$ \\
\hline$\mu_{\mathrm{A} 1}$ & $=$ & kemampuan \\
\hline & & pemecahan masalah fisika siswa \\
\hline & & yang diajarkan dengan \\
\hline & & $\begin{array}{l}\text { menggunakan model direct } \\
\text { instruction }\end{array}$ \\
\hline$\mu_{\mathrm{A} 2}$ & $=$ & Rata-rata kemampuan \\
\hline & & pemecahan masalah fisika siswa \\
\hline & & yang diajarkan dengan \\
\hline & & menggunakan model PBL \\
\hline$\mu_{\mathrm{B} 1}$ & $=$ & Rata-rata kemampuan \\
\hline & & pemecahan masalah fisika siswa \\
\hline & & untuk kelompok siswa yang \\
\hline & & $\begin{array}{l}\text { mempunyai kemampuan berfikir } \\
\text { kritis rendah }\end{array}$ \\
\hline$\mu_{\mathrm{B} 2}$ & $=$ & kemampuan \\
\hline & & pemecahan masalah fisika siswa \\
\hline & & untuk kelompok siswa yang \\
\hline & & empunyai kemampuan berfikir \\
\hline
\end{tabular}

\section{HASIL DAN PEMBAHASAN}

Untuk melihat perbedaan kemampuan berpikir kritis dan kemampuan pemecahan masalah siswa terhadap pembelajaran yang diberikan, digunakan uji
Jurnal Pendidikan Fisika p-ISSN2252-732X e-ISSN 2301-7651

Two Way Anova dengan analisis varians 2x2 sekaligus untuk melihat bagaimana pengaruh tingkat kemampuan berpikir kritis siswa terhadap kemampuan pemecahan masalah siswa- Apakah siswa yang memiliki kemampuan berpikir kritis di atas rata-rata memiliki kemampuan pemecahan masalah yang tinggi atau sebaliknya lebih rendah, serta apakah terdapat interaksi antara model pembelajaran dengan tingkat kemampuan berpikir kritis dalam mempengaruhi kemampuan pemecahan masalah siswa.

Tabel 2. Desain_Faktorial Rata-Rata 2 × 2 Anava

\begin{tabular}{lccc}
\hline $\begin{array}{c}\text { Kemampuan } \\
\text { Berpikir } \\
\text { Kritis }\end{array}$ & \multicolumn{2}{c}{ Kemampuan } & \multicolumn{2}{c}{$\begin{array}{c}\text { Pemecahan Masalah } \\
\end{array}$} & $\begin{array}{c}\text { Kelas } \\
\text { Model } \\
\text { DI }\end{array}$ & $\begin{array}{c}\text { Kelas } \\
\text { Model PBL }\end{array}$ & $\begin{array}{c}\text { Rata- } \\
\text { Rata }\end{array}$ \\
\hline KBK & 84 & 94 & 87 \\
$\begin{array}{l}\text { Dibawah } \\
\text { rata-rata }\end{array}$ & & & \\
$\begin{array}{l}\text { KBK } \\
\text { Di atas rata- } \\
\text { rata }\end{array}$ & 92 & 98 & 96 \\
Rata-rata & 86 & 97 & \\
\hline
\end{tabular}

Tabel 3. Hasil Uji Anava Dua Jalur

\begin{tabular}{llrr}
\hline \multicolumn{1}{c}{ Source } & \multicolumn{1}{c}{ Mean } & F & Sig \\
\hline Corrected & & 105,125 &, 000 \\
Model & 780,889 & 59019,41 &, 000 \\
Intercept & 438406,91 & 102,472 & \\
Kelas & 7 & 68,081 &, 000 \\
Kemamp & & 8,489 &, 000 \\
uan & 761,179 & &, 005 \\
berpikir & & & \\
Kritis & 505,717 & & \\
Kelas*Ke & & & \\
mampuan & 63,057 & & \\
Berpikir & & & \\
Kritis & 7,428 & & \\
Error & & & \\
\hline
\end{tabular}

Dari tabel 3 hasil uji anava dua jalur yang dipaparkan, selanjutnya digunakan untuk menjawab hipotesis-hipotesis yang diajukan dalam penelitian ini. Berikut deskripsi hasil uji hipotesis tersebut.

Hasil interaksi antara model penibelajaran dan tingkat kemampuan berpikir kritis dalam mempengaruhi kemampuan pemecahan rnasalah juga dapat disajikan dalarn bentuk grafik. Gambar 1. menunjukkan grafik interaksi antara model pembelajaran dan kemampuai berpikir kritis. Gambar 1. hasil interaksi antara model pembelajaran dengan tingkat kemampuan berpikir kritis di atas tidak dapat dilihat secara langsung adanya perpotongan garis yang terjadi di suatu titik, namun apabila garis diperpanjang akan terlihat perpotongan garis. Hal ini menunjukkan interaksi antara model 
U. S. Z. Nasution, Sahyar, M. Sirait: Pengaruh Model Problem Based Learning dan Kemampuan Berfikir Kritis Terhadap Kemampuan Pemecahan Masalah

pembelajaran dan kemampuan berpikir kritis dalam penelitian ini kecil dengan $F$ hitung sebesar 0,005.

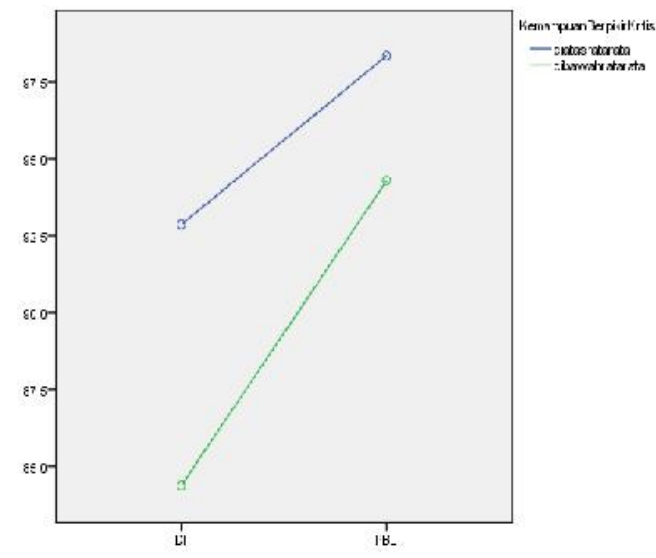

Gambar 1. Interaksi antara model pembelajaran berbasis masalah (PBL) dan pembelajaran direct instruction dengan kemampuan berpikir kritis

\section{PEMBAHASAN}

Perbedaan Kemampuan Pemecahan Masalah Fisika Siswa Menggunakan Model Pembelajaran Problem Based Learning dengan Model Direct Instruction, Hasil yang signifikan dalam penelitian ini bisa disebabkan karena aktivitas pembelajaran berbasis masalah cenderung mengajak siswa untuk belajar lebih aktif, selain itu pembelajaran berbasis masalah membantu siswa untuk mengembangkan kemampuan penyelesaian masalah dalam kegiatan diskusi, dimana kegiatan diskusi mengkondisikan siswa bekerja dalam tim, menemukan ide, dan mengembangkan berpikir siswa dalam menyelesaikan masalah sehingga suatu proses interaksi sosial dengan teman lain dalam kegiatan diskusi memacu terbentuknya ide baru dan memperkaya perkembangan intelektual siswa.

Sedangkan kelas konvensional, siswa cenderung menerima pembelajaran secara satu arah dan kurang dihadapkan dengan masalah yang memandirikan siswa dalam mengembangkan pemahamannya sendiri. Selain itu, kegiatan bertukar pikiran antara siswa pada kelas konvensional berlangsung kurang efektif brena pada proses pembelajaran guru lebih berperan banyak dalam penyebaran pengetahuan.

Hal inilah yang sesuai dengan pendapat Melek \& Belma (2010) yang mengungkapkan pembelajaran berbasis masalah menyediakan lingkungan fimgsional yang mana pelajar bersama teman dan dukungan guru menerima rekomendasi dan timbal balik ketika mengahadapi permasalahan yang mana kegiatan pembelajaran berganti dan satu arah ke berbagai arah disertai masalah dan ketersediaan solusi. Selain itu Alper, A., (2008) juga berpendapat siswa terlihat lebih
Jurnal Pendidikan Fisika p-ISSN2252-732X e-ISSN 2301-7651

berani dalam mengembangkan hipotesis untuk memecahkan masalah dan mempunyai kemampuan lebih untuk menguji dan mengeliminasi hipotesis, sedangkan tanpa diskusi siswa lebin ragu dalam mengeliminasi hipotesis. Redhana, I.,W., (2013) juga berpendapat pembelajaran berbasis masalah menyediakan masalah-masalah kurang terstruktur. Masalah kurang terstruktur adalah masalah yang tidak mengandung informasi yang lengkap dan semua informasi yang tersedia dalarn masalah tidak cukup untuk memecahkan masalah tersebut. Oleh karena itu., untuk dapat memecahakan masalah tersebut, mahasiswa harus mengumpulkan informasi tambahan dan berbagai sumber. Bahkan, informasi tambahan ini harus dikumpulkan dalam jumlah yang banyak agar siswa dapat memecahkan masalah kurang terstruktur tersebut dengan baik.

Perbedaan kemampuan pemecahan masalah fisika siswa pada kelompok siswa dengan kemampuan berpikir kritis di atas rata-rata dan kelompok siswa dengan kemampuan berpikir kritis di bawah rata-rata, Tingginya nilai kemampuan pemecahan masalah ini bisa disebabkan karena siswa yang memiliki kemampuan berpikir kritis tinggi memiliki kematangan pengetahuan dalam menyelesaikan suatu permasalahan, selain itu cenderung memiliki keinginan untuk menemukan dan meneliti lebih tinggi dibandingkan siswa dengan kemampuan berpikir kritis rendah. Hal ini terlihat pada saat siswa melaksanakan kegiatan analisis dan pemecahan masalah, siswa. dengan kemampuan berpikir kritis tinggi lebih terbuka dan aktif pada kegiatan diskusi dengan cara menanyakan kesulitan-kesuljtan yang dihadapi. Siswa dengan kemampuan berpikir knitis tinggi juga menunjukkan kecenderungan menyukai tugas yang berat dan sulit serta menemukan jawaban yang luas dan memuaskan hal inilah yang menyebabkan kemampuan pemecahan masalah siswa meningkat. Berbeda halnya dengan siswa yang memiliki kemampuan berpikir kritis rendah, siswa cenderung tidak memperdulikan permasalahan yang dihadapi dan tidak memiliki hasrat ingin tahu serta bersikap diam tidak rnau mengeluarkan pendapat terhadap suatu pengalaman baru, akibatnya sulit untuk melaksanakan kegiatan pembelajaran yang menuntut aktivitas tinggi serta menguras pemikiran. Siswa juga tidak memiliki keinginan untuk menginvestigasi dan mencari pemecahan solusi dan suatu permasalahan yang diberikan, akibatnya siswa tidak menyukai tugas yang berat dan sulit Hal ini tampak pada kegiatan pembelajaran, siswa dengan kemampuan berpikir kritis rendah menunjukkan aktivitas yang rendah, baik dalam pengorganisasian, pelaksanaan kegiatan investigasi maupun kegiatan penyajian hasil dan laporan yang telah dilakukan. Kecenderungan-kecenderungan tersebut mengakibatkan siswa dengan kemampuan berpikir kritis rendah tidak memiliki kemampuan menganalisa dan mensintesis permasalah yang dihadapi. Hal mi sejalan 
U. S. Z. Nasution, Sahyar, M. Sirait: Pengaruh Model Problem Based Learning dan Kemampuan Berfikir Kritis Terhadap Kemampuan Pemecahan Masalah

dengan pendapat E1-Shaer, A., dan Hala, G., (2014) bahwa pembelajaran berbasis masalah berkontribusi menolong siswa untuk berpartisipasi secara aktif dalam kelas perawat, menyediakan kemampuan berpikir kritis yang memungkinkan siswa untuk melengkapi kebutuhan harapan dan menggunakan pengetahuan dalani membuat materi pelajaran lebih menarik dan lebih relevan. Sedangkan Thoman, las (2009) mengungkapkan perkembangan berpikir adalah elemen berpikir kritis dalam hubungan pendlikan berkelanjutan. Masek, A dan Sulaiman, Y., (2011), PBL mempunyai potensi yang besar dalam membantu mengembangkan kemampuan berpikir tingkat tinggi khusvsnya kemampuan berpikir kritis.

Interaksi antara

pembelajaranberbasis masalah dan model pembelajaran konvensional dengan kemampnan berpikir kritis terhadap kemampuan pemecahan masalah fisika siswa, Hasil pengujian dengan menggunakan uji schefe dalam melihat interaksi model pembelajaran dengan kemampuan berpikir kritis dalam meningkatkan kemampuan pemecahan masalah fisika siswa diperoleh hasil yang signifikan. Terdapat interaksi dalam penelitian ini bisa disebabkan karena kemampuan berpikir kritis siswa berperan penting dalam kematangan intelektual siswa. Selain itu pembelajaran berbasis masalah yang merupakan pembelajaran berpusat pada siswa membutuhkan pengetahuan pengembangan kemampuan berpikir dalam menyelesaikan suatu permasalahan terhadap situasi atau lingkungan belajar yang tidak siswa ketahui. Dan dengan pembelajaran ini siswa yang memiliki kemampuan berpikir kritis tinggi diajak untuk berpikir secara aktif dan partisipatif mencari informasi, menganalisis dan memecahkan masalah dengan menggunakan sumber pembelajaran yang sesuai dengan permasalahan yang dihadapi. Sebaliknya model pembelajaran yang berinteraksi dengan kemampuan berpikir kritis rendah akan berinteraksi dengan hasil prestasi belajar yang rendah terhadap kemampuan pemecahan masalah. Hal ini dikarenakan siswa dengan kemampuan berpikir kritis rendah cenderung tidak mau tahu dan kurang paham dalam memecahkan suatu permasalahan yang siswa sulit dalam melakukan analisis, mengolah dan melaksanajcan kegiatan pembelajaran yang menuntut aktivitas tinggi serta menguras pemikiran.

Temel, Senar (2014) juga mengungkapkan hal yang sama, bahwa pembelajaran berbasis masalah mempunyai pengaruh positif dalam disposisi pemikiran kritis dan persepsi kemampuan pemecahan masalah. Terlebih guru dalam pembelajaran ini memperkenalkan sebuah pendekatan pembelajaran yang berbeda dari metode tradisional yaitu keterlibatan dalam Iingkungan belajar yang tidak diketahui, yang diakui sebagai alasan yang tidak hanya cukup tingkatan kanahiran kemampuan berpikir, tetapi dalam proses ini, guru diberikan peluang dalam mengembangkan
Jurnal Pendidikan Fisika p-ISSN2252-732X

e-ISSN 2301-7651

pembagian pemikiran kritis dan persepsi kemampuan pnecahan masalah. Dimana secara khusus, pembelajaran yang berpusat pada siswa harus digunakan di kelas yang memungkjnkan pengembangan kemampuan diposisi berpikir kritis dan persepsi kemampuan pemecahan masalah.

\section{KESIMPULAN}

1. Terdapat perbedaan kemampuan pemecahan masalah fisika siswa melalui model pembelajaran berbasis masalah (problem based learning) dengan model pembelajaran direct instruction, Dimana nilai rata-rata pembelajaran berbasis masalah 97,09 yang berarti lebih baik jika dibandingkan kelas direct intruction dengan nilai rata-rata 86,60.

2. Terdapat perbedaan kemampuan pemecahan masalah fisika siswa antara kelompok siswa yang memiliki kemampuan berpikir kritis di atas rata rata dengan kelompok siswa yang memiliki kemampuan berpikir kritis di bawah rata - rata, dan kemampuan pemecahan masalah fisika siswa yang memiliki kemampuan berpikir kritis di atas rata rata 98,36 lebih baik jika dibandingkan kelas direct intructional 92,87.

3. Terdapat interaksi antara model pembelajaran berbasis masalah (problem based learning) dan kenampuan berpikir kritis dalam meningkatkan keterampilan pemecahan masalah fisika siswa dengan hasil interaksi pada kelas problem based learning sebesar 10,49 lebih baik dibanding direct intruction. Namun perbedaan kemampuan pemecahan masalah dengan kemampuan berpikir kritis tinggi kelas eksperimen tidak terdapat perbedaan yang signifikan. Hal tersebut dikarenakan kelas direct instruction yang berperan dominan dalam proses pembelajaran adalah tingkat kemampuan berpikir kritis sedangkan di kelas problem based learning yang berperan dominan dalam pembelajaran adalah model pembelajaran PBL.

\section{REFERENSI}

Dwi, I, M., Arif, H., \& Sentot, K. (2013). Pengaruh Strategi Problem Based Learning Berbasis ICT Terhadap Pemahaman Konsep dan Kemampuan Pemecahan Masalah Fisika. Jurnal Pendidikan Fisika Indonesia, 9 : 8-17

Fisher, Alec. (2009). Berpikir Kritis:Sebuah Pengantar. Terjemahan oleh Benyamin Hadinata. Jakarta: Erlangga.

Harahap, M.B. (2013). Strategi Pembelajaran Fisika. Medan: Unimed

Heller,P. (1991). Teaching Problem Solving Through Cooperative Grouping Part I: Group Versus Individuals Problem Solving. Am.J.Phys.60,627-636. 
U. S. Z. Nasution, Sahyar, M. Sirait: Pengaruh Model Problem Based Learning dan Kemampuan Berfikir Kritis Terhadap Kemampuan Pemecahan Masalah

Indrawati. (2000). Keterampilan Proses Sains: Tinjauan Kritis dari Teori ke Praktis. Depdikbud: Bandung.

Jonassen. (2004). Learning to Solve Problems, An Instructional Desaign Guide. San Fransisco : John Wiley \& Sons, Inc

Joyce, B. (1992). Models of Teaching (fourth ed.). Massachusetts: Allyn and Bacon.

..............(2000). Models of Teaching (Sixth ed.). Boston: Allyn and Bacon.

(2011). Models of Teaching (Sixth ed.). Boston: Allyn and Bacon

Joko,Tri, Wakhid Ahdinirwanto, Arif Maftukhin. 2013. Peningkatan Kemampuan Berpikir Kritis Melalui Model Pembelajaran Children Learning In Science (CLIS) pada Siswa Kelas VIII SMP Negeri 1 Mirit Tahun Pelajaran 2012/2013.

Liliasari (2005). Membangun Keterampilan Berfikir Manusia Indonesia Melalui Pendidikan Sains. Naskah Pidato Pengukuhan jabatan Guru Besar Tetap Dalam Ilmu Pendidikan IPA pada Fakultas FMIPA UPI : Bandung.
Jurnal Pendidikan Fisika p-ISSN2252-732X

e-ISSN 2301-7651

Ormrod, Jeanne Ellis.(2008). Psikologi Pendidikan Membantu Siswa Tumbuh dan Berkembang Jilid 1. Jakarta : Erlangga.

Permendiknas No 22 Thn (2006). Standar isi SMP

Polya, G. (1985). How To Solve It. $2^{\text {nd }}$ ed., Princeton University Press, ISBN 0-691-08097-6. (online). Tersedia

http://www.math.utah.edu/ pa /math/polya..html [20 Nopember 2013]

Posamentier, Alfred S. and Jay Steppelman.(1999). Teaching Secondary Mathematics : technique and Enrichment Units. New Jersey : Prenticehall, Inc.

Sanjaya, Wina. (2009). Strategi Pembelajaran Berorientasi Standart Proses Pendidikan. Jakarta: Kencana Prenada Media Group.

Santrock, John W. (2007). Perkembangan Anak. Jakarta :PT Gelora Aksara Pratama Erlangga

Selcuk, S, G., Caliskan, S., Erol, M. (2008). The Effects of Problem Solving Instruction on Physics Achievement, Problem Solving Performance and Strategy Use. Lat. Am. J. Phys. Educ, 2 (3) : 151-166. Tersedia: http://www.journal.lapen.org.mx [29 